\title{
Albizia zygia (DC.) Macbr. Hydroethanol Root Extract Exerts Anti- Oedemic and In Vivo Antioxidant Activities in Animal Models
}

\author{
Stanley Benjamin Lamptey ${ }^{*}$, Wonder Kofi Mensah Abotsi \\ Department of Pharmacology, Faculty of Pharmacy and Pharmaceutical Sciences, College of Health Sciences, Kwame Nkrumah Univer sity of Science and \\ Technology, Kumasi, Ghana.
}

\begin{tabular}{ll}
\hline ARTICLE INFO & ABSTRACT \\
\cline { 3 - 4 } $\begin{array}{l}\text { Article history: } \\
\text { Received on: } 30 / 01 / 2017 \\
\text { Accepted on: } 26 / 03 / 2017 \\
\text { Available online: } 30 / 04 / 2017\end{array}$ & $\begin{array}{l}\text { Various parts of Albizia zygia (DC.) Macbr. (Family: Leguminosae-Mimosoideae) are used traditionally in the } \\
\text { management of arthritis and pain. The present study evaluated the anti-inflammatory and in vivo antioxidant } \\
\text { effects of the hydroethanolic root extract of Albizia zygia in animal models. Oedema was induced by the } \\
\text { injection of carrageenan (2\% suspension) into the right footpads of } 7 \text {-day old chicks. The footpad thickness was } \\
\text { measured hourly for } 5 \mathrm{~h} \text {. Carrageenan was also administered into rat paw subcutaneous tissues, which } \\
\text { subsequently induced oxidative stress and inflammation at the injected site. After } 5 \mathrm{~h} \text { the rats were sacrificed } \\
\text { and inflamed paw tissues isolated for antioxidant enzyme analysis. The extract (30-300 mg/kg, p.o.) and the } \\
\text { Inflammation, oxidative } \\
\text { stress, oedema, carrageenan, } \\
\text { antioxidant. }\end{array}$ \\
$\begin{array}{l}\text { positive control, diclofenac (3-30 mg/kg, i.p.), significantly attenuated pedal oedema when given either pre- } \\
\text { emptively or curatively. The extract also augmented the endogenous expression of superoxide dismutase (SOD), } \\
\text { catalase (CAT) and reduced glutathione (GSH) as well as reduced the activity of myeloperoxidase (MPO) and } \\
\text { malondialdehyde (MDA) level at the inflamed site. The results suggest that the hydroethanolic extract of } \text { Albizia } \\
\text { zygia exerts in vivo anti-inflammatory activity after oral administration and also has antioxidant properties } \\
\text { which may contribute to its activity. }\end{array}$ \\
\hline
\end{tabular}

\section{INTRODUCTION}

Inflammation is a biological response of an organism's immune system to cellular and vascularized tissue damage(Nathan, 2002). Inflammation when gone awry, initiates an innocent bystander attack on the host cells within hours after trauma. The local release of toxic metabolites and enzymes destroy uninjured tissue (Stahel et al., 2007). Tissue injury can generate reactive oxygen species (ROS) by releasing transition metal ions from damaged cells, activating phagocytes or generating NO (Aruoma, 1998). The phagocytes also generate $\mathrm{O}_{2}{ }^{--}, \mathrm{H}_{2} \mathrm{O}_{2}$ and $\mathrm{HOCl}$ to kill pathogens. The overproduction of these ROS can further worsen tissue damage (Aruoma, 1998).

* Corresponding Author

E-mail:pappywhyte @ gmail.com
Many medicinal plant sources have been investigated as alternate medications for managing injury-induced inflammation. In this study the roots of Albizia zygia (DC.) Macbr. (Family: Leguminosae-Mimosoideae), was investigated for its activity in acute inflammation. Its potential antioxidant effect was also evaluated in vivo. Albizia zygia, also known as West African Walnut, Okuro (Ghana), Nyie avu (Igbo), Ayinre were (Yoruba), Red Nongo (Uganda) or Nongo (Swahili). It is indigenous to West and East Africa, India and Australia (Anim-Kwapong et al., 1995; Orwa et al., 2009). The bark and leaf decoctions are used traditionally in the management of waist pain, fever and venereal diseases (Arbonnier, 2004; Ndjakou Lenta et al., 2007). Root bark formulations are used to treat venereal diseases (Ndjakou Lenta et al., 2007). A. zygia exhibits cytotoxicity against human Tlymphoblast-like leukaemia, prostate and breast cancer cell lines (Appiah-Opong et al., 2016). 
The methanol stem bark extract is very active in malaria and sleeping sickness (Arbonnier, 2004; Abdalla et al., 2012). Since there is scanty scientific documentation on the efficacy of $A$. zygia roots in the traditional management of inflammation, the present study validates such folkloric use of the plant.

\section{MATERIAL AND METHODS}

\section{Plant material collection}

Albizia zygia roots were collected from the campus of Kwame Nkrumah University of Science and Technology (KNUST), Kumasi, Ghana $\left(6^{\circ} 40^{\prime} 31.8^{\prime \prime N}\right.$; $\left.1^{\circ} 34^{\prime} 44.1^{\prime \prime} \mathrm{W}\right)$ in the month of January, 2015. The root sample was authenticated by Dr. George Henry Sam in the Department of Herbal Medicine, Faculty of Pharmacy and Pharmaceutical Sciences, KNUST. A voucher specimen (no: KNUST/H/M/2016/R001) has been preserved in the Faculty herbarium.

\section{Preparation of extract}

The roots were room-dried for 2 weeks, and then pulverized into fine powder. The powder was cold macerated with $70 \%(\mathrm{v} / \mathrm{v})$ ethanol. The hydro-alcoholic supernatant was filtered and then concentrated to a brown syrupy mass under reduced pressure at $50^{\circ} \mathrm{C}$ in a rotary evaporator (R-210, BUCHI, Switzerland). The extract was further dried in a hot air oven at $50^{\circ} \mathrm{C}$ and stored at $4^{\circ} \mathrm{C}$ until use. The final product, of yield $9.03 \%\left({ }^{\mathrm{w}} / \mathrm{w}\right)$, is subsequently referred to as AZE or extract in this study.

\section{Phytochemical screening}

Preliminary phytochemical tests were carried out on AZE according to methods described by Trease and Evans (Trease et al., 1989) and Sofowora (Sofowora, 1993).

\section{Animals}

Cockerels (Gallus gallus; strain Shaver 579, Akropong Farms, Kumasi, Ghana) were obtained one-day post-hatch and housed in stainless steel cages $(34 \mathrm{~cm} \times 57 \mathrm{~cm} \times 40 \mathrm{~cm})$ at a population density of 12-13 chicks per cage. Feed (Agricare Ltd, Kumasi, Ghana) and water were available ad libitum through 1-qt gravity-fed feeders and waterers. Overhead incandescent illumination was provided with room temperature at $29^{\circ} \mathrm{C}$. Chicks were tested at 7 days of age. Group sample sizes of six were utilized throughout the study.

Sprague-Dawley rats (100-200 g) of both sexes acquired from Noguchi Memorial Institute of Medical Research (NMIMR), University of Ghana, Accra were grouped $(n=6)$ in stainless steel colony cages. Animals had free access to chow (Agricare Ltd, Kumasi, Ghana), and were provided water ad lib. The animals were humanely handled in all experiments according to the internationally accepted principles concerning animal protection in experimental protocols (EU Directive of 2010; 2010/63/EU). In addition, ethical approval was granted by the Ethics Committee of the Department (FPPS/PCOL/010/2015).

\section{Drugs and chemicals}

The enlisted drugs and chemicals were used: $\lambda$ carrageenan, trichloroacetic acid (TCA), thiobarbituric acid (TBA), potassium dichromate, Tris(hydroxymethyl) aminomethane, Triton X-100, EDTA, sodium bicarbonate, 5,5dithio bis-2-nitrobenzoic acid (DTNB) (Sigma-Aldrich Inc., St. Louis, MO, USA); diclofenac sodium (Troge, Hamburg, Germany); sodium dihydrogen orthophosphate monohydrate (Hopkins \& Williams Ltd, Swansea, Wales); analytical grade glacial acetic acid, ethanol, hydrogen peroxide, chloroform and disodium hydrogen phosphate (BDH, Poole, England); Complete Protease Inhibitor Cocktail Tablet, EDTA-free (Santa Cruz Biotechnology, Dallas, TX, USA).

\section{Carrageenan-induced pedal oedema test}

The acute anti-oedemic effect of AZE was investigated in the carrageenan-induced oedema model in chicks (Roach and Sufka, 2003; Abotsi et al., 2012). A volume of $10 \mu$ carrageenan suspension $(2 \% \mathrm{w} / \mathrm{v})$ was administered into the chicks' right footpads. Dorso-ventral ipsilateral pedal thickness was measured initially $(0 \mathrm{~h})$ and at every hour post-carrageenan administration for $5 \mathrm{~h}$ (using electronic callipers Z22855, Milomex Ltd, Bedfordshire, UK) (Murayama et al., 1991). Oedema was calculated as the normalized percentage change in foot thickness from time $0 \mathrm{~h}$ using the equation: $\%$ change in pedal thickness $=\left[\left(\mathrm{V}_{\mathrm{t}}-\mathrm{V}_{0}\right) / \mathrm{V}_{0} \times 100\right]$; where, $\mathrm{V}_{0}$ is carrageenan preadministration pedal thickness $(0 \mathrm{~h})$ and $\mathrm{V}_{\mathrm{t}}$ is carrageenan postadministration pedal thickness (at time $t$ ).

Two sets of experiments, prophylactic and curative, were performed. Drug administration were made $30 \mathrm{~min}$ (intraperitoneal) or $1 \mathrm{~h}$ (oral) pre-carrageenan challenge in the prophylactic experiment; or $1 \mathrm{~h}$ post-carrageenan in the curative protocol. Chicks were grouped according to their drug treatments $(\mathrm{n}=6-7)$. The treatments groups were: vehicle control $(10 \mathrm{ml} / \mathrm{kg}$ of $2 \%$ tragacanth, p.o.), AZE suspended in $2 \%$ tragacanth (30-300 $\mathrm{mg} / \mathrm{kg}$, p.o.) or diclofenac (3-30 mg/kg, i.p.).

\section{In vivo antioxidant assay}

The assay of endogenous antioxidants was carried out according to the protocol prescribed by Halici et al. (2007). Intraplantar carrageenan administration was made into the subcutaneous paw tissues of rats, which subsequently induced oxidative stress at the inflamed site. Rats were assigned into eight groups $(n=3)$ with respective drug treatments as follows: experimental naïve control (normal saline; $10 \mathrm{ml} / \mathrm{kg}$; i.p.), vehicle control $(2 \% \mathrm{w} / \mathrm{v}$ tragacanth, $10 \mathrm{ml} / \mathrm{kg} ;$ p.o. $)$, AZE suspended in $2 \%$ tragacanth (30-300 mg/kg, p.o.) or diclofenac (3-30 mg/kg, i.p.). General intraplantar introduction of $100 \mu \mathrm{l}$ carrageenan $(1 \% \mathrm{w} / \mathrm{v})$, either $30 \mathrm{~min}$ (i.p.) or $1 \mathrm{~h}$ (p.o) post-drug administration, induced oedema in the right hind paw. Five hours after carrageenan administration, rats were sacrificed by cervical dislocation. Oedematous paw tissues were harvested and immediately stored at $-80^{\circ} \mathrm{C}$ for subsequent enzyme analysis. A volume of $4.5 \mathrm{ml}$ of TNG buffer at $\mathrm{pH} 7.4(150 \mathrm{mM}$ Tris $\mathrm{HCl}, 150 \mathrm{mM} \mathrm{NaCl}, 1 \%$ 
Triton X 100, 10\% glycerol and protease inhibitor cocktail) was added to each sample, and homogenized on ice using a homogenizer (Ultra-Turrax T-25; IKA-Labortechnik, Staufen, Germany) at $24000 \times g$ for $15 \mathrm{~min}$. Each sample was centrifuged at $4000 \times g$ for $20 \mathrm{~min}$, decanted and preserved for enzyme analysis. Sample protein content was calculated using the Bradford method (Bradford, 1976). All subsequent microtiter plate readings were carried out in triplicates.

\section{Superoxide dismutase (SOD) assay}

The activity of superoxide dismutase (SOD) was measured according to the method of Misra and Fridovich (1972). A volume of $500 \mu \mathrm{l}$ homogenate was centrifuged in $150 \mu \mathrm{l}$ of icecold chloroform and $750 \mu \mathrm{l}$ ethanol $(96 \% \mathrm{v} / \mathrm{v})$ at $2000 \times g$ for 20 min. Successive additions of $1 \mathrm{ml}$ carbonate buffer $(0.1 \mathrm{M} ; \mathrm{pH}$ $10.2)$ and $0.5 \mathrm{ml}$ EDTA $(0.6 \mathrm{mM})$ were made to $500 \mu \mathrm{l}$ of supernatant aliquot. A $1.3 \mathrm{mM}$ adrenaline solution of volume 0.05 $\mathrm{ml}$ was then added to initiate adrenochrome formation. A blank solution containing all reagents except tissue homogenate was processed in a similar manner. A volume of $150 \mu \mathrm{l}$ was then dispensed into a 96-well plate. Absorbance was read spectrophotometrically at $480 \mathrm{~nm}$ using Synergy H1 Multi-mode Reader (BioTek Technologies, Winooski, VT, USA). The percentage inhibition of adrenaline autoxidation was calculated as:

$$
\% \text { inhibition }=\left(\frac{\text { Absorbance }_{\text {test }}-\text { Absorbance }_{\text {blank }}}{\text { Absorbance }_{\text {test }}}\right) \times 100
$$

Specific SOD activity was expressed in units per $\mathrm{mg}$ protein, where 1 unit is the enzyme quantity needed to prevent $50 \%$ of the autoxidation of adrenaline at $25^{\circ} \mathrm{C}$; calculated using the formula:

$$
\text { Unitsof SODactivity } / \text { mgprotein }=\left(\frac{\% \text { inhibition }}{50 \times \text { wtofprotein }}\right)
$$

\section{Catalase (CAT) assay}

The test principle is based on the propensity of CAT to hydrolyse $\mathrm{H}_{2} \mathrm{O}_{2}$, thereby inhibiting the dichromate in acetic acid reduction to chromic acetate by $\mathrm{H}_{2} \mathrm{O}_{2}$ (Sinha, 1972). Successive additions of $0.4 \mathrm{ml} \mathrm{H}_{2} \mathrm{O}_{2}(1.18 \mathrm{M})$ and $1 \mathrm{ml}$ phosphate buffer $(0.01$ $\mathrm{M}$; pH 7.0) were made to $0.1 \mathrm{ml}$ of homogenate and incubated for $5 \mathrm{~min}\left(25^{\circ} \mathrm{C}\right)$. A $2 \mathrm{ml}$ dichromate-acetic acid mixture (containing 3 parts glacial acetic acid and 1 part $5 \%$ potassium dichromate) was then added to terminate the reaction. A volume of $150 \mu \mathrm{l}$ of the mixture was pipetted into a 96-well plate. Chromogenate absorbance was calorimetrically read at $620 \mathrm{~nm}$.

Specific CAT activity was expressed as units per $\mathrm{mg}$ protein based on the molar extinction coefficient of $\mathrm{H}_{2} \mathrm{O}_{2}, 39.4 \mathrm{M}$ $1 \mathrm{~cm}-1$ at $620 \mathrm{~nm}$. One unit is the enzyme quantity needed to hydrolyse $1 \mathrm{mmol}$ of $\mathrm{H}_{2} \mathrm{O}_{2} / \mathrm{min}$ in a neutral $\mathrm{pH}\left(25^{\circ} \mathrm{C}\right)$, i.e.

$$
\begin{gathered}
\text { mUnitof CATactivity/mgprotein }=\left(\frac{\text { Absorbance }_{620 \mathrm{~nm}}}{39.4 \times \text { wtofprotein }}\right) \\
\times 1000
\end{gathered}
$$

\section{Reduced glutathione (GSH) assay}

The concentration of GSH in inflamed paw was measured by the procedure stated by Ellman (1959). To $100 \mu \mathrm{l}$ of the homogenate was added $2.4 \mathrm{ml} 0.02 \mathrm{M}$ EDTA; solution was then cooled at $4{ }^{\circ} \mathrm{C}$ for $10 \mathrm{~min}$. Additions of $2 \mathrm{ml} \mathrm{H}_{2} \mathrm{O}$ and $0.5 \mathrm{ml}$ of $50 \% \mathrm{w} / \mathrm{v}$ TCA were made to the mixture and centrifuged at 3000 $\times \mathrm{g}$ for $5 \mathrm{~min}$. About $50 \mu \mathrm{l}$ of $10 \mathrm{mM}$ DTNB solution and $2 \mathrm{ml}$ of Tris buffer ( $0.4 \mathrm{M}$; pH 8.9) were then thoroughly mixed with $1 \mathrm{ml}$ of the supernatant and the reaction incubated for $5 \min \left(25^{\circ} \mathrm{C}\right)$. A reaction mixture was repeated also for the blank. The wells of 96well plate were filled with $150 \mu \mathrm{l}$ of mixture and absorbance was spectrophotometrically read at $412 \mathrm{~nm}$. GSH concentration was expressed in $\mu$ mol per $\mathrm{mg}$ protein, and determined using the curve $y=0.0004 x+0.0026$.

\section{Myeloperoxidase (MPO) assay}

Enzyme concentration was determined spectrophotometrically by a modified $o$-dianisidine method (Şenoğlu et al., 2009). An assay mixture-consisting of $5 \mathrm{ml} 0.02$ $\mathrm{M} o$-dianisidine $+3 \mathrm{ml} \mathrm{H}_{2} \mathrm{O}_{2}(0.01 \mathrm{M})+3 \mathrm{ml}$ phosphate buffer (0.1 M; pH 6.0) and made up to $30 \mathrm{ml}$-was freshly prepared. About $125 \mu \mathrm{l}$ aliquot of it was dispensed into a 96-well microtiter plate and topped up with $0.01 \mathrm{ml}$ of tissue homogenate. The absorbance increase was straightway read at $460 \mathrm{~nm}$ in $60 \mathrm{~s}$ cycles for $600 \mathrm{~s}$. MPO specific activity was expressed in units per mg protein, where 1 unit increases absorbance by 0.001 per $60 \mathrm{~s}$.

$$
\begin{aligned}
& \text { Unit of MPO } / \text { mgprotein } \\
= & \left(\frac{\text { Absorbance }_{460 \mathrm{~nm}} / \mathrm{min}}{0.001 \times\left(\text { totalprotein }_{10} \text { ulaliquot }\right)}\right)
\end{aligned}
$$

\section{Lipid peroxidation assay}

MDA levels were determined by a modified protocol (Heath et al., 1968). To a $1 \mathrm{ml}$ volume of homogenate was mixed $3 \mathrm{ml}$ of the mixture ( $3 \mathrm{ml}$ of $20 \%$ TCA containing $0.5 \%$ TBA) in a test tube. It was heated at $95^{\circ} \mathrm{C}$ for $30 \mathrm{~min}$, cooled immediately and then centrifuged at $5000 \times g$ for $10 \mathrm{~min}$. Absorbance was initially read at $532 \mathrm{~nm}$ and then read again at $600 \mathrm{~nm}$ to correct for nonspecific absorbance. The molar extinction coefficient of MDA-TBA abduct, $155 \mathrm{mM}^{-1} \mathrm{~cm}^{-1}$, was used to determine the levels of MDA from the equation:

nmolMDA/mgprotein

$$
=\frac{\text { Absorbance }_{532 \mathrm{~nm}-\text { Absorbance }_{600 \mathrm{~nm}}}}{155 \times \text { totalprotein }^{6}} \times 10^{6}
$$

\section{Analysis of data}

Statistical analyses and $\mathrm{ED}_{50}$ determinations were done using GraphPad Prism for Windows version 6 (GraphPad Software, San Diego, CA, USA). The time course curves were analyzed by two-way repeated measures analysis of variance (ANOVA). The mean treatment differences at each time period were compared by Tukey's post hoctest. Subsequent area under the curves (AUCs) were then calculated (arbitrary units) to 
determine the total treatment effect. One-way ANOVA was used to analyse the AUC mean differences; pair-wise comparisons were done using Tukey's post hoc test. $P<0.05$ between treatments was considered statistically significant.

\section{RESULTS}

\section{Phytochemical screening}

Alkaloids, tannins, flavonoids, saponins, glycosides and terpenoids were found to be present in AZE.

\section{Carrageenan-induced pedal oedema test}

The introduction of $10 \mu \mathrm{l}$ of $2 \%$ carrageenan suspension into pedal tissues of chicks effectuated an acute local oedema. Oedema peaked at 2-3 $\mathrm{h}$ in all paws (Figures 1 and 2), correlating with the findings of treatments across the time courses of AZE $(30-300 \mathrm{mg} / \mathrm{kg}$; p.o.) and diclofenac $(3-30 \mathrm{mg} / \mathrm{kg}$, i.p.)(Roach and Sufka, 2003). Figures 1(a, c) and 2(a, c) represent the time course of effects of the respective treatments. The column graphs of AZE and diclofenac are represented in Figure $1(b, d)$ for preemptive and Figure 2(b, d) for curative treatments respectively.

Analysis of the curves with respect to the vehicle control group shows a significant reduction in the mean maximal paw oedema at $2-3 \mathrm{~h}$ by AZE (prophylaxis: $F_{3,20}=10.87, P<0.0001$; therapeutic: $F_{3,24}=6.107, P=0.0031$ ) and diclofenac (prophylaxis: $F_{3,99}=97.64, P<0.0001$; therapeutic: $\left.F_{3,24}=20.32, P<0.0001\right)$. Total oedema was significantly reduced by the treatments. AZE demonstrated maximal inhibition of mean total oedema by $57.65 \pm 6.70 \%$ (pre-emptive) and $55.41 \pm 7.37 \%$ (curative) at dose $300 \mathrm{mg} / \mathrm{kg}$. Diclofenac also similarly inhibited the mean total oedema by $77.08 \pm 3.80 \%$ (pre-emptive) and $75.87 \pm 4.00 \%$ (curative) at $30 \mathrm{mg} / \mathrm{kg}$. Figure 3 compares the dose-response relationships of $\mathrm{AZE}$ and diclofenac. The $\mathrm{ED}_{50}$ values of $\mathrm{AZE}$ and diclofenac (obtained by non-linear regression) were 195.2 \pm 63.98 $\mathrm{mg} / \mathrm{kg}$ (pre-emptive); $1650 \pm 6.63 \mathrm{mg} / \mathrm{kg}$ (curative) and $1.43 \pm 0.69$ $\mathrm{mg} / \mathrm{kg}$ (pre-emptive); $38.05 \pm 1.49 \mathrm{mg} / \mathrm{kg}$ (curative) respectively.
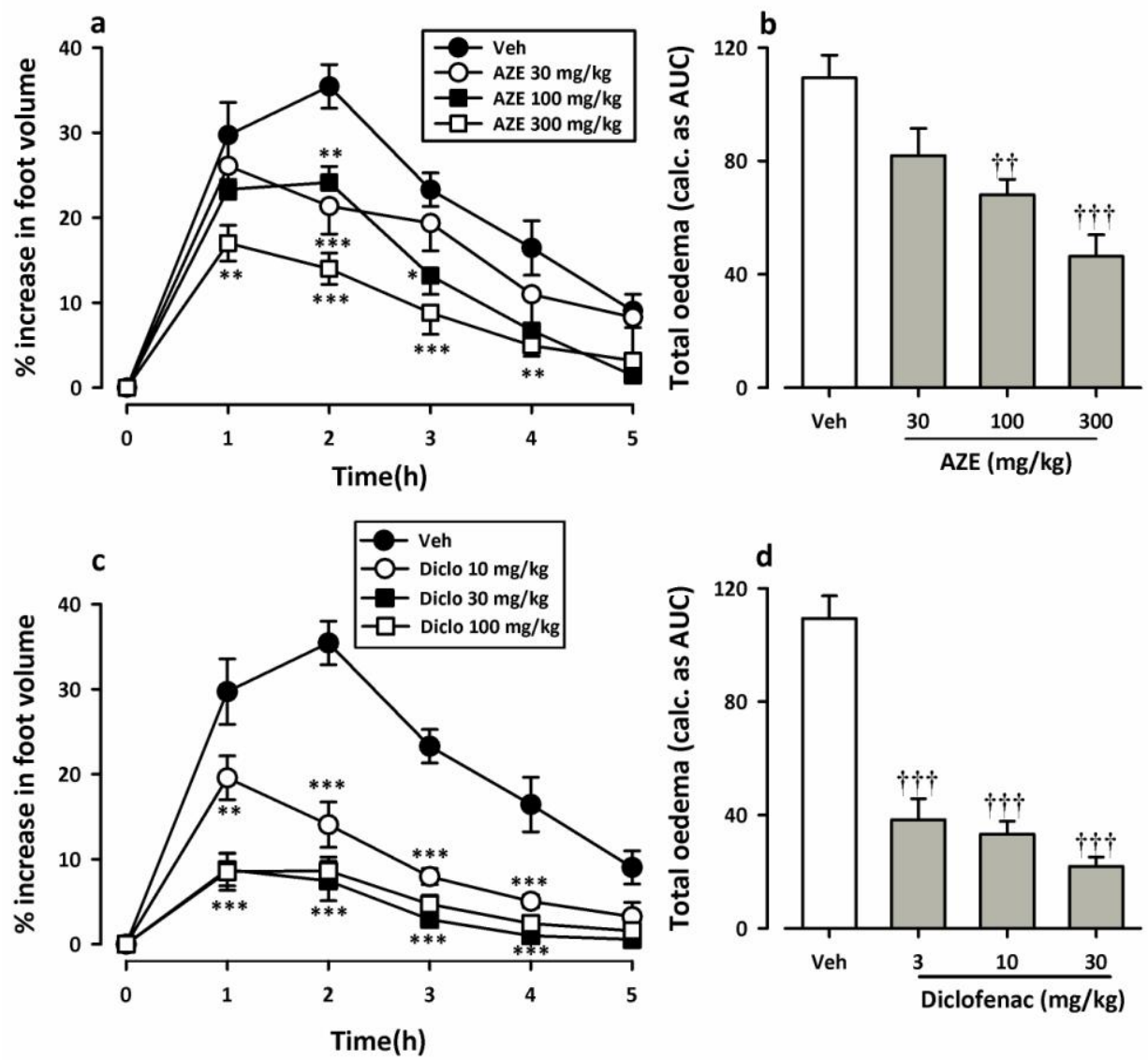

Fig. 1: Effect of AZE (30-300 mg/kg; p.o.) and diclofenac (3-30 mg/kg, i.p.) on time-course curves (a and c respectively) and the total oedema response (b and d respectively) in the prophylactic protocol of the carrageenan-induced foot oedema in chicks.

Values are mean \pm S.E.M. $(\mathrm{n}=6){ }^{* * * * * * * *} \mathrm{P}<0.05 /<0.01 /<0.001$ versus vehicle control (Two-way ANOVA; Tukey’s post hoc test). $\dagger_{\dagger}^{\dagger \dagger} \mathrm{P}<0.01 /<0.001$ versus vehicle control (One-way ANOVA; Tukey’s post hoc test). 

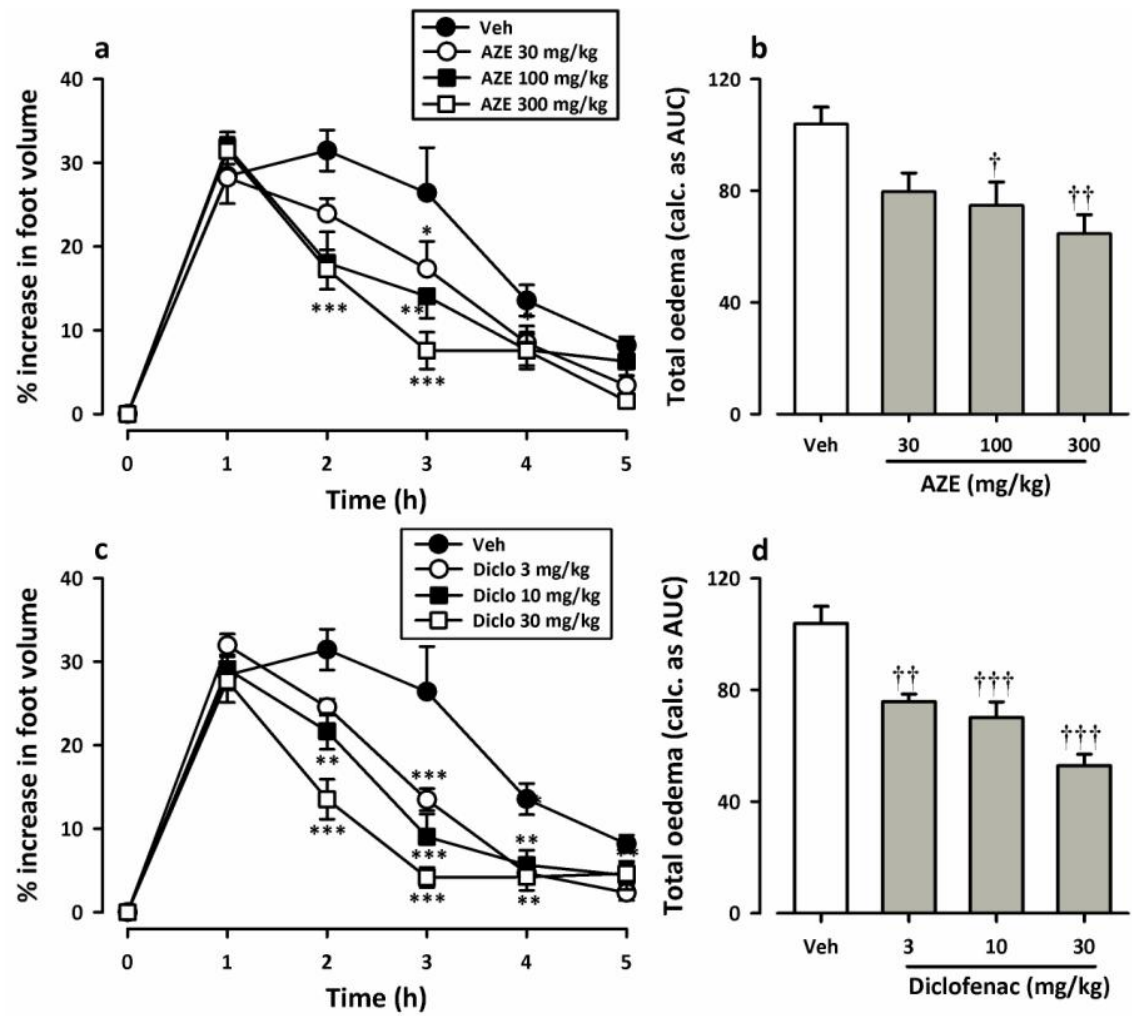

Fig. 2: Effect of AZE (30-300 mg/kg, p.o.) and diclofenac (3-30 mg/kg, i.p.) on time-course curves (a and c respectively) and the total oedema response ( $b$ and $d$ respectively) in the curative protocol of the carrageenan-induced foot oedema in chicks. Values are mean $\pm S . E . M(n=6)$.

$* / * * * * * * \mathrm{P}<0.05 /<0.01 /<0.001$ versus vehicle control (Two-way ANOVA; Tukey post hoc test).

$+1 / \uparrow \dagger+\uparrow \dagger \mathrm{P}<0.05 /<0.01 /<0.001$ versus vehicle control (One-way ANOVA; Tukey post hoc test).
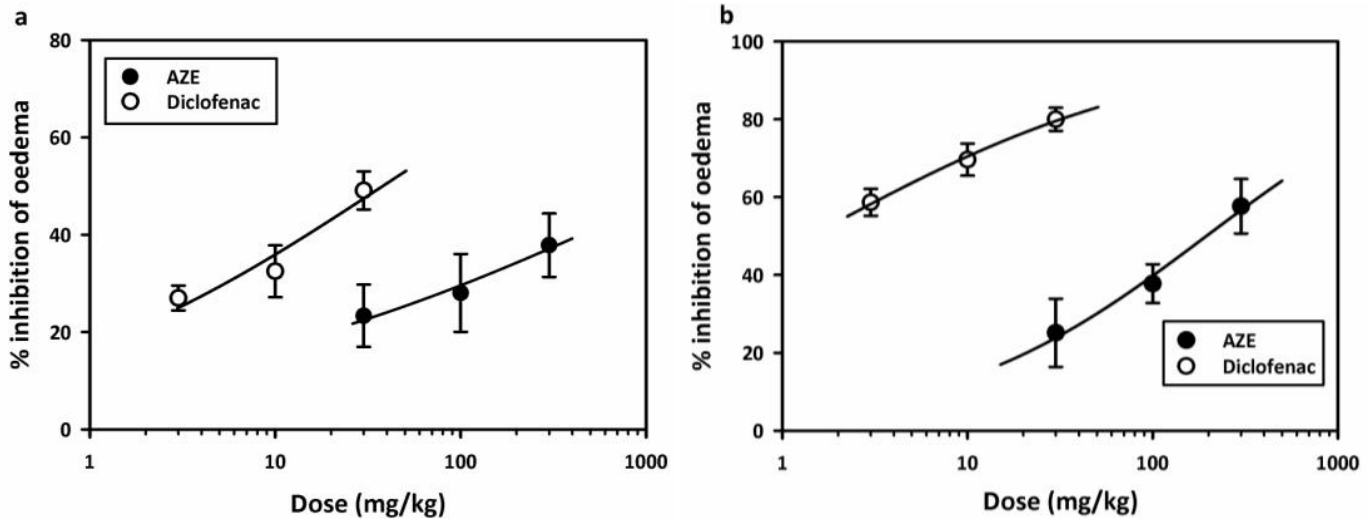

Fig. 3: Dose-response curves for AZE (10-300 mg/kg, p.o) and diclofenac (3-30 mg/kg, i.p) in the prophylactic (a) and curative (b) protocols of carrageenan-induced foot oedema in the chick.

Table 1 Effect of AZE and diclofenac on the levels of SOD, CAT, MPO, GSH and MDA.

\begin{tabular}{|c|c|c|c|c|c|}
\hline Group & $\begin{array}{c}\text { SOD } \\
\text { (mU/mg prot.) }\end{array}$ & $\begin{array}{c}\text { CAT } \\
\text { (mU/mg prot.) }\end{array}$ & $\begin{array}{c}\text { MPO } \\
\text { (U/mg prot.) }\end{array}$ & $\begin{array}{c}\text { GSH } \\
(\mu \mathrm{mol} / \mathrm{mg} \text { prot. })\end{array}$ & $\begin{array}{c}\text { MDA } \\
\text { (nmol/mg prot.) }\end{array}$ \\
\hline Control & $398.37 \pm 35.95^{\dagger}$ & $43.44 \pm 3.59$ & $279.84 \pm 53.89$ & $353.16 \pm 23.64^{\text {तो }}$ & $151.87 \pm 15.04^{\dagger \dagger}$ \\
\hline Vehicle & $192.47 \pm 18.19$ & $26.22 \pm 3.43$ & $499.18 \pm 43.11$ & $135.37 \pm 21.60$ & $504.11 \pm 49.97$ \\
\hline AZE $30 \mathrm{mg} / \mathrm{kg}$ & $253.15 \pm 16.14$ & $40.04 \pm 1.77$ & $382.11 \pm 74.74$ & $80.04 \pm 23.26$ & $263.15 \pm 61.32^{\text {** }}$ \\
\hline AZE $100 \mathrm{mg} / \mathrm{kg}$ & $370.56 \pm 25.61^{*}$ & $55.48 \pm 0.81^{* *}$ & $184.20 \pm 99.96^{*}$ & $246.65 \pm 19.31$ & $188.22 \pm 20.20^{* * * *}$ \\
\hline AZE $300 \mathrm{mg} / \mathrm{kg}$ & $431.08 \pm 32.28^{* *}$ & $59.45 \pm 1.55^{* *}$ & $207.87 \pm 67.81$ & $308.48 \pm 20.69^{* * *}$ & $168.33 \pm 25.86^{* * * *}$ \\
\hline Diclo $3 \mathrm{mg} / \mathrm{kg}$ & $371.69 \pm 44.63^{*}$ & $57.85 \pm 4.50^{* *}$ & - & $185.20 \pm 36.67$ & $250.86 \pm 38.71^{\text {*** }}$ \\
\hline Diclo 10 mg/kg & $521.95 \pm 23.21^{* * * *}$ & $74.36 \pm 5.38^{* * * *}$ & - & $305.19 \pm 18.57^{* *}$ & $177.00 \pm 42.28^{* * * *}$ \\
\hline Diclo $30 \mathrm{mg} / \mathrm{kg}$ & $661.79 \pm 54.12^{* * *}$ & $85.91 \pm 9.94^{* * *}$ & $211.49 \pm 57.47^{*}$ & $360.57 \pm 32.82^{* * * *}$ & $135.64 \pm 8.71^{* * *}$ \\
\hline
\end{tabular}

Values are mean \pm SEM $(\mathrm{n}=3) .{ }^{* / \uparrow} P<0.05,{ }^{* *} P<0.01,{ }^{* / T \dagger} P<0.001$ compared to vehicle-treated group (One-way ANOVA followed by Tukey's post hoc test). SOD: Superoxide dismutase; CAT: Catalase; MPO: Myeloperoxidase; GSH: reduced glutathione; MDA: Malondialdehyde; Prot: protein 


\section{In vivo antioxidant assay Superoxide dismutase assay}

The vehicle-treated group showed a marked reduction in SOD activity at the inflamed site compared to that in the naive subjects (Table 1). AZE (100 and $300 \mathrm{mg} / \mathrm{kg}$; p.o.)-treated rats had a significant increase in SOD activity $\left(F_{4,10}=13.91, P=0.0004\right)$. A dose-dependent effect was obtained for diclofenac $\left(F_{4,10}=21.71\right.$, $P<0.0001)$.

\section{Catalase assay}

The intraplantar carrageenan administration induced an acute local inflammation in the rat paw with resultant oxidative stress. The oxidative stress caused a marked reduction in CAT levels in negative control group compared to the naïve group (Table 1). On the other hand, AZE (100 and $300 \mathrm{mg} / \mathrm{kg}$; p.o.) and diclofenac $\left(3-30 \mathrm{mg} / \mathrm{kg}\right.$; i.p.) increased CAT activity $\left(F_{7,16}=16.24\right.$, $P<0.0001)$. The lowest dose of AZE produced no significant change in CAT activity but a dose-dependent effect was seen with diclofenac.

\section{Reduced glutathione assay}

Increased oxidative imbalance significantly reduced GSH concentration (Table 1). Preemptive administration of AZE (300 $\mathrm{mg} / \mathrm{kg}$, p.o.) and diclofenac (10 and $30 \mathrm{mg} / \mathrm{kg}$, i.p.), however, significantly increased GSH expression in the rat paw $\left(F_{7}\right.$, $\left.{ }_{16}=16.81, P<0.0001\right)$.

\section{Myeloperoxidase assay}

MPO activity increased in the negative control group relative to naïve group (Table 1). AZE and diclofenac pretreatments significantly reversed the increased MPO concentration in their respective groups $\left(F_{5,11}=3.221, P=0.0493\right)$. The significant effects were seen in only AZE $100 \mathrm{mg} / \mathrm{kg}$ (p.o.) and diclofenac 30 $\mathrm{mg} / \mathrm{kg}$ (i.p.)

\section{Lipid peroxidation assay}

Oxidative stress increases lipid peroxidation with a resultant increase in malondialdehyde generated from the decomposition of lipid hydroperoxides. The measurement of MDA levels revealed an increased concentration in negative control group relative to the naïve group (Table 1). The administration of AZE (30-300 mg/kg, p.o.) and diclofenac (3-30 mg/kg, i.p.) significantly and dose-dependently reduced MDA levels $\left(F_{7}\right.$, $\left.{ }_{16}=10.47, P<0.0001\right)$.

\section{DISCUSSION}

This present study has established that oral administration of the hydroethanolic root extract of Albizia zygia has anti-inflammatory and antioxidant properties in animals.

Carrageenan-induced pedal oedema in chicks is simple to conduct, reproducible and highly reliable. Overdependence on rodent models is curtailed by replacing rodents with a less sentient species, chicks(Fereidoni et al., 2000; Roachand Sufka, 2003).
Carrageenan administration produces a local inflammation with no systemic effects and no antigenicity. Pedal oedema in chicks lasts approximately $6 \mathrm{~h}$, peaking $2 \mathrm{~h}$ post-carrageenan injection. Subcutaneous injection of carrageenan induces a biphasic inflammation characterized by oedema, erythema and pain. Proinflammatory mediators- histamine, serotonin, bradykinin, tachykinins, complement and ROS are responsible for inducing the inflammation (Morris, 2003). Prostaglandins then induce the last phase of the oedema; as a result of the action of inducible forms of nitric oxide synthase (iNOS) and cyclooxygenase (COX-2) (Posadas et al., 2004). Preemptive and curative administration of AZEto chicks significantly suppressed the acute local oedema in both treatment protocols. The anti-oedemic effects of AZE may possibly be attributable to the inhibition of synthesis, release and/or activity of the inflammatory mediators. The precise mechanism by which AZE suppresses inflammation however needs to be established. AZE was compared to the standard antiinflammatory analgesic, diclofenac. It is a non-selective COX inhibitor which prevents the synthesis of the arachidonic acid metabolites such as prostaglandins, thromboxanes and leukotrienes (Gan, 2010). The body's generation of ROS helps maintain homeostasis in the cells of a healthy tissue. They also serve as signaling molecules (Devasagayam et al., 2004). Oxidative imbalance abounds in inflamed tissues after trauma. The relative diminution of endogenous antioxidants increase cellular susceptibility to oxidative damage(Wang et al., 2004; Valerio et al., 2009). Free radicals possess short half-lives and are less concentrated; as such oxidative damage is best assessed by measuring the amount of products and enzymes produced (Hovatta et al., 2010). SOD converts $\mathrm{O}_{2}{ }^{-}$to $\mathrm{H}_{2} \mathrm{O}_{2}$, and then either CAT or GPx converts the $\mathrm{H}_{2} \mathrm{O}_{2}$ to oxygen and water. GSH and its congeners detoxify peroxynitrites, hydroperoxides and electrophiles such as reactive aldehydes (malondialdehyde, MDA). MPO is used by neutrophils to synthesize $\mathrm{HOCl}$ during phagocytic lysis of foreign bodies (Zhu et al., 2008; Şenoğlu et al., 2009; Halliwell, 2012). Histamine, serotonin and eicosanoids mediate the early phase of the carrageenan-induced paw oedema whilst polymorphonuclear infiltration is responsible for the delayed inflammatory phase. Neutrophil-derived $\mathrm{OH}, \mathrm{H}_{2} \mathrm{O}_{2}$ and $\mathrm{O}_{2}{ }^{-{ }^{-}}$, MPO and MDA concentrations are augmented whilst antioxidant levels are reduced in the paw tissue(Bilici et al., 2002; Halici et al., 2007). Pretreatment of the rats with AZE significantly elevated the activities/levels of the preventive enzyme antioxidants (SOD and CAT) and the scavenger, chain breaking or repair antioxidant, $\mathrm{GSH}$, at the inflamed site. AZE also reduced the formation of MDA and the pro-inflammatory enzyme MPO. Similar results were obtained for diclofenac. The anti-inflammatory effect of AZE may at least partly be as the result of the prevention of oxidative damage.

\section{CONCLUSION}

In conclusion, the hydroethanol extract of the roots of Albizia zygia demonstrated anti-oedemic and in vivo antioxidant 
activity in animals. The results validate the folkloric use of $A$. zygia in the treatment of inflammatory disorders.

\section{ACKNOWLEDGEMENTS}

The authors are grateful to the technical staff of the Department of Pharmacology for their assistance.

\section{Financial support and sponsorship: Nil.}

Conflict of Interests: There are no conflicts of interest.

\section{REFERENCES}

Abdalla MA, Laatsch H. Flavonoids from Sudanese Albizia zygia (Leguminosae, subfamily Mimosoideae), a plant with antimalarial potency. African Journal of Traditional, Complementary, and Alternative Medicines: AJTCAM / African Networks on Ethnomedicines, 2012; 9:5658.

Abotsi WK, Ainooson GK, Woode E. Anti-inflammatory and antioxidant effects of an ethanolic extract of the aerial parts of Hilleria latifolia (Lam.) H. Walt. (Phytolaccaceae). African Journal of Traditional, Complementary, and Alternative Medicines : AJTCAM / African Networks on Ethnomedicines, 2012; 9:138-152.

Anim-Kwapong G, Teklehaimanot Z. Reclamation of degraded cocoa lands using Albizia zygia. Land Degradation \& Development, 1995; 6:109-123.

Appiah-Opong R, Asante IK, Safo DO, Tuffour I, Ofori-attah E, Uto T, Nyarko AK. Cytotoxic Effects of Albizia zygia (DC) JF Macbr, a Ghanaian Medicinal Plant, Against Human T-Lymphoblast-Like Leukemia, Prostate and Breast Cancer Cell Lines. International Journal of Pharmacy and Pharmaceutical Sciences, 2016; 8:392-396

Arbonnier M. 2004.Trees, shrubs and lianas of West African dry zones.Paris, France: CIRAD, Margraf Publishers Gmbh, MNHN

Aruoma OI. Free radicals, oxidative stress, and antioxidants in human health and disease. Journal of the American Oil Chemists' Society, 1998; 75:199-212.

Bilici D, Akpinar E, Kiziltunc A. Protective effect of melatonin in carrageenan-induced acute local inflammation. Pharmacological Research, 2002; 46:133-139.

Bradford MM. A rapid and sensitive method for the quantitation of microgram quantities of protein utilizing the principle of protein-dye binding. Analytical Biochemistry, 1976; 72:248-254.

Devasagayam T, Tilak J, Boloor K, Sane KS, Ghaskadbi SS, Lele R. Free radicals and antioxidants in human health: current status and future prospects. The Journal of the Association of Physicians of India, 2004; 52:4.

Ellman GL. Tissue sulfhydryl groups. Archives of Biochemistry and Biophysics, 1959; 82:70-77.

Fereidoni M, Ahmadiani A, Semnanian S, Javan M. An accurate and simple method for measurement of paw edema. Journal of Pharmacological and Toxicological Methods, 2000; 43:11-14.

Gan TJ. Diclofenac: an update on its mechanism of action and safety profile. Current Medical Research and Opinion, 2010; 26:17151731.

Halici Z, Dengiz GO, Odabasoglu F, Suleyman H, Cadirci E, Halici M. Amiodarone has anti-inflammatory and anti-oxidative properties: an experimental study in rats with carrageenan-induced paw edema. European Journal of Pharmacology, 2007; 566:215-221.

Halliwell B. Free radicals and antioxidants: updating a personal view. Nutrition Reviews, 2012; 70:257-265.

Heath RL, Packer L. Photoperoxidation in isolated chloroplasts: I. Kinetics and stoichiometry of fatty acid peroxidation. Archives of biochemistry and biophysics, 1968; 125:189-198.

Hovatta I, Juhila J, Donner J. Oxidative stress in anxiety and comorbid disorders. Neuroscience Research, 2010; 68:261-275.
Misra HP, Fridovich I. The role of superoxide anion in the autoxidation of epinephrine and a simple assay for superoxide dismutase. Journal of Biological chemistry, 1972; 247:3170-3175.

Morris CJ. Carrageenan-induced paw edema in the rat and mouse. Inflammation Protocols, 2003:115-121.

Murayama M, Mori T, Bando H, Amiya T. Studies on the constituents of Aconitum species. IX. The pharmacological properties of pyro-type aconitine alkaloids, components of processed aconite powder 'kako-bushi-matsu': analgesic, antiinflammatory and acute toxic activities. Journal of Ethnopharmacology, 1991; 35:159-164.

Nathan C. Points of control in inflammation. Nature, 2002; 420:846-852.

Ndjakou Lenta B, Vonthron-Senecheau C, Fongang Soh R, Tantangmo F, Ngouela S, Kaiser M, Tsamo E, Anton R, Weniger B. In vitro antiprotozoal activities and cytotoxicity of some selected Cameroonian medicinal plants. Journal of Ethnopharmacology, 2007; 111:8-12.

Orwa C, Mutua A, Kindt R, Jamnadass R, Simons A. Agroforestree Database: a tree reference and selection guide version 4.0. World Agroforestry Centre, Kenya, 2009; 15.

Posadas I, Bucci M, Roviezzo F, Rossi A, Parente L, Sautebin L, Cirino G. Carrageenan-induced mouse paw oedema is biphasic, age-weight dependent and displays differential nitric oxide cyclooxygenase-2 expression. British Journal of Pharmacology, 2004; 142:331-338.

Roach JT, Sufka KJ. Characterization of the chick carrageenan response. Brain research, 2003; 994:216-225.

Şenoğlu M, Kurutaş EB, Altun I, Atli Y, Nacitarhan V. Myeloperoxidase Activities in Polymorphonuclear Leukocytes in Lumbar Disc Disease. Journal of Neurological Sciences, 2009; 26: 292-297

Sinha AK. Colorimetric assay of catalase. Analytical Biochemistry, 1972; 47:389-394.

Sofowora A. 1993. Medicinal Plants and Traditional medicine in Africa. Ibadan: Spectrum Books Ltd.

Stahel PF, Smith WR, Moore EE. Role of biological modifiers regulating the immune response after trauma. Injury, 2007; 38:1409-1422.

Trease GE, Evans WC. 1989. A Textbook of Pharmacognosy. London: Baillière Tindall.

Valerio DA, Georgetti SR, Magro DA, Casagrande R, Cunha TM, Vicentini FT, Vieira SM, Fonseca MJ, Ferreira SH, Cunha FQ, Verri WA, Jr. Quercetin reduces inflammatory pain: inhibition of oxidative stress and cytokine production. Journal of Natural Products, 2009; 72:1975-1979.

Wang ZQ, Porreca F, Cuzzocrea S, Galen K, Lightfoot R, Masini E, Muscoli C, Mollace V, Ndengele M, Ischiropoulos H, Salvemini D. A newly identified role for superoxide in inflammatory pain. The Journal of Pharmacology and Experimental Therapeutics, 2004; 309:869878.

Zhu H, Zhang L, Amin AR, Li Y. Coordinated upregulation of a series of endogenous antioxidants and phase 2 enzymes as a novel strategy for protecting renal tubular cells from oxidative and electrophilic stress. Experimental biology and medicine, 2008; 233:753-765

\section{How to cite this article:}

Lamptey SB, Abotsi WKM. Albizia zygia (DC.) Macbr. Hydroethanol Root Extract Exerts Anti-Oedemic and In Vivo Antioxidant Activities in Animal Models. J App Pharm Sci, 2017; 7 (04): 199-205. 